\title{
Treatment of refractory juvenile chronic arthritis by monoclonal CD4 antibodies: a pilot study in two children
}

\author{
Gerd Horneff, Uta Dirksen, Hendrik Schulze-Koops, Frank Emmrich, Volker Wahn
}

\begin{abstract}
Objective-To study the effect of anti-CD4 treatment in patients suffering from refractory systemic onset juvenile chronic arthritis (JCA).

Methods-Two children were treated with the mouse CD4 antibody MAX.16H5. The effects on numbers of circulating CD4 T cells, clinical symptoms and $\mathrm{C}$ reactive protein (CRP) level were studied and the appearance of human antimouse immunoglobulin antibodies investigated. Results-In patient one, disappearance of fever and malaise and a reduction of arthritic activity were observed together with a reduction in CRP. When disease activity returned eight weeks later, a second successful course of treatment was administered. It was possible to reduce the corticosteroid dosage permanently. In the other child, a first treatment cycle did not alter disease activity. A marked reduction in clinical and laboratory disease activity markers was observed after the second course. Only transient and mild side effects were observed. One patient exhibited a short lasting febrile reaction with chills, the other an urticarial rash. In both patients, human antibodies to mouse immunoglobulin became detectable. The decrease in the number of CD4 $T$ cells in the peripheral blood was only short lasting and numbers returned to normal values within one to eight weeks, even after the second course of antibody treatment and under concomitant immunosuppressive treatment. No sustained clinical remissions could be achieved.

Conclusions-These preliminary observations support the evidence of positive effects of CD4 antibody treatment in refractory systemic onset JCA. Long term efficacy, however, remains to be established.
\end{abstract}

(Ann Rheum Dis 1995; 54: 846-849)

CD4 positive $\mathrm{T}$ cells are thought to play an important part in the pathogenesis of rheumatoid arthritis (RA). ${ }^{1}$ Use of monoclonal antibodies to $\mathrm{CD} 4$ therefore seemed promising, and more than 100 adult RA patients have been treated to date. ${ }^{2-7}$ Twelve
RA patients with refractory disease were treated with the CD4 antibody MAX.16H5, resulting in significant improvement in clinical and laboratory parameters (reported previously, ${ }^{3}$ and unpublished observations). Major side effects have yet to be observed. Concomitant immunological investigations demonstrated only transient depletion of CD4 $\mathrm{T}$ cells and monocytes. ${ }^{8} \mathrm{~A}$ possible mechanism of action of the CD4 antibody is the inhibition of $T$ cell activation by blocking interactions between CD 4 molecules on $\mathrm{T}$ cells and major histocompatibility complex (MHC) class II molecules on antigen presenting cells, thereby interrupting the physical association of $T$ cell receptor and $\mathrm{CD} 4$ which is critical for $\mathrm{T}$ cell activation. This may lead to modulation of cytokine secretion, and indirectly also to modulation of antibody production. Furthermore, CD4 antibodies might reduce monocyte-macrophage activation, with a decreased secretion of proinflammatory cytokines. ${ }^{8}$ The results of the studies with MAX.16H5 in adult RA patients prompted us to use MAX.16H5 to treat two children with severe and active systemic onset juvenile chronic arthritis (JCA) in whom conventional treatments had failed.

\section{Patients and methods}

The study was approved by the ethics committee of the University of Düsseldorf. Written informed consent was obtained from both patients and their parents. The mouse monoclonal CD4 antibody MAX.16H5 (IgG1 isotype) had been prepared according to the procedures of the European Community Committee for Proprietary Medicinal Products ${ }^{9}$ and had been used previously in adults. ${ }^{3}$ It was diluted in a human albumin solution $(0.2 \mathrm{mg})$ $\mathrm{ml}$ ) and administered intravenously in a dosage of approximately $0.3 \mathrm{mg} / \mathrm{kg}$ body weight over a period of four to six hours every morning on seven consecutive days. As our experience with repeat treatment after six to eight weeks had given promising results in adult RA patients, the treatment was repeated eight weeks later in the two children.

Ritchie index ${ }^{10}$ and joint swelling were used to evaluate clinical response. The patients were questioned as to the duration of morning stiffness, and their global assessment of their condition was recorded by a $10 \mathrm{~cm}$ visual analogue scale $(10=$ bad $\ldots 0=$ good $)$. All

Germany.

Accepted for publication 16 May 1995 
clinical examinations were performed between 09:00 and 10:00, by the same physician (UD). Routine laboratory tests included leucocyte counts and differential leucocyte counts, erythrocyte sedimentation rate, haemoglobin, biochemistry, immunoglobulins, $\mathrm{C}$ reactive protein, complement components, and urine analysis. For cellular immunological investigations, peripheral blood mononuclear cells were separated by standard Ficoll-Hypaque centrifugation methods. ${ }^{11}$ Surface marker analysis of lymphocyte subsets was performed by direct or indirect immunofluorescence by flow cytometry using a Becton-Dickinson FACSScan. Human antimouse antibody activity was measured as described previously. ${ }^{12}$

\section{Results}

The table summarises details of the first patient-a 13 year old boy. JCA (known as juvenile rheumatoid arthritis (JRA) in the USA) was diagnosed according to the criteria of the JRA subcommittee of the American College of Rheumatology (ACR). ${ }^{13} \mathrm{He}$ suffered from unremitting systemic onset JCA for two years. Perimyocarditis had occurred in the first year of the disease. Intermittent high grade fever, rash, and polyarthritis with marked synovitis could not be controlled by several immunosuppressive agents which had been given at commonly recommended doses for several months. Before receiving anti-CD4 treatment, the patient had intermittent increases in body temperature to $38^{\circ} \mathrm{C}$ while receiving $2 \times 100 \mathrm{mg}$ cyclosporin $(5 \mathrm{mg} / \mathrm{kg}$ body weight) and $15 \mathrm{mg}$ prednisolone $(0.35$ $\mathrm{mg} / \mathrm{kg}$ ) per day, which could not be reduced without provoking reappearance of high grade fever. After anti-CD4 treatment, the increased temperatures disappeared, as did the resting joint pain. A $50 \%$ reduction in the Ritchie index and disappearance of morning stiffness were noted at the end of the one week course of treatment. All clinical response criteria demonstrated clear benefit from the treatment and he tolerated prednisone $10 \mathrm{mg}$ per day $(0.23 \mathrm{mg} / \mathrm{kg})$. When disease activity flared again eight weeks later, cyclosporin $\mathrm{A}$ was concluded to be totally ineffective and discontinued. A second anti-CD4 treatment was performed with an even better response compared with the first treatment (figure). Symptoms of systemic illness such as fever and rash did not return during the next two months. CRP levels decreased from $157 \mathrm{mg} / 1$ to $37 \mathrm{mg} / \mathrm{l}$ in parallel with the response to the first treatment and increased again to $144 \mathrm{mg} / \mathrm{l}$ just before the second treatment, after which no significant change in CRP was observed.

The second patient was an 11 year old girl in whom systemic onset JCA began at the age of 30 months and proved resistant to conventional treatment (table). Because of recurrent fever, prednisone $0.3 \mathrm{mg} / \mathrm{kg}$ was introduced. Anti-CD4 treatment was added to a drug regimen that had included weekly methotrexate $\left(15 \mathrm{mg} / \mathrm{m}^{2}\right)$ for the past two years. Although a first treatment cycle had failed to improve her condition, a second course of anti-CD4 treatment was successful. A marked reduction of synovitis and joint tenderness, and an $80 \%$ decrease in Ritchie index were observed. Morning stiffness totally disappeared (figure). The steroid dosage was reduced a little (to prednisone $0.2 \mathrm{mg} / \mathrm{kg}$ daily). CRP levels decreased only moderately from $136 \mathrm{mg} / \mathrm{l}$ to $115 \mathrm{mg} / \mathrm{l}$ in response to treatment one and from $148 \mathrm{mg} / \mathrm{l}$ to $100 \mathrm{mg} / \mathrm{l}$ in response to treatment two.

After the first infusion of MAX.16H5, the number of CD4 $\mathrm{T}$ cells decreased markedly, from $1312 / \mu \mathrm{l}$ to $62 / \mu \mathrm{l}$ in the boy and from $1164 / \mu 1$ to $71 / \mu l$ in the girl. Labelling of CD4 epitopes in vivo by the therapeutic antibody was demonstrated by staining with fluorescein isothiocyanate conjugated goat antimouse serum (data not shown). One day after the full treatment cycle had been completed the number of $\mathrm{CD} 4 \mathrm{~T}$ cells was moderately decreased in the boy $(720 / \mu \mathrm{l})$, and low in the girl $(96$ cells $/ \mu \mathrm{l})$. Both the number of CD4 cells and the CD4:CD8 ratio returned to normal values $(1155 / \mu 1$ and $1229 / \mu 1$, respectively) within eight weeks. When the second course of treatment was given, again, there was a decrease in the number of CD4 positive cells with a return to normal values over a period of four to eight weeks. All changes were similar to those described in adults. ${ }^{3}$

Both first treatment courses were tolerated without side effects. After the first infusion of the second treatment course, the boy developed an urticarial rash, but further infusions were tolerated well. The girl had a sharp flare of fever up to $39.5^{\circ} \mathrm{C}$ with chills after the first antibody infusion of the second course of treatment, but tolerated

Details of two young patients with $\mathcal{F C A}$, treated with $C D 4$ antibody

\begin{tabular}{|c|c|c|}
\hline & Patient 1 & Patient 2 \\
\hline Age (years)/Sex/Weight (kg) & $13 / \mathrm{M} / 42$ & $11 / F / 32$ \\
\hline Duration of disease (years) & & \\
\hline Disease presentation & Pericarditis, rash, intermittent fever, polyarthritis & Rash, intermittent fever, polyarthritis \\
\hline $\begin{array}{l}\text { Rheumatoid factor } \\
\text { Antinuclear antibodies }\end{array}$ & Negative & - \\
\hline Previous DMARD treatment & Gold (weekly up to $1 \mathrm{mg} / \mathrm{kg}$ im), & $\begin{array}{l}\text { Negative } \\
\text { Pulse steroids (iv } 20 \mathrm{mg} / \mathrm{kg} \text { on three }\end{array}$ \\
\hline & $\begin{array}{l}\text { azathioprine (daily } 3 \mathrm{mg} / \mathrm{kg} \text { ), } \\
\left.\text { methotrexate (weekly up to } 15 \mathrm{mg} / \mathrm{m}^{2}\right) \\
\text { cyclosporin (daily } 5-6 \mathrm{mg} / \mathrm{kg} \text { ), } \\
\text { iv immunoglobulins }(2 \mathrm{~g} / \mathrm{kg} \text { every four weeks) }\end{array}$ & $\begin{array}{l}\text { consecutive days every four weeks), } \\
\text { azathioprine (daily } 3 \mathrm{mg} / \mathrm{kg} \text { ), } \\
\text { methotrexate (up to } 20 \mathrm{mg} / \mathrm{m}^{2} \text { weekly), } \\
\text { iv immunoglobulins ( } 2 \mathrm{~g} / \mathrm{kg} \text { every four } \\
\text { weeks) }\end{array}$ \\
\hline Concomitant treatment & $\begin{array}{l}\text { Diclofenac } 3 \times 25 \mathrm{mg} \text {, } \\
\text { prednisone } 15 \mathrm{mg}(\text { reduced to } 10 \mathrm{mg} \S) \\
\text { cyclosporine } 2 \times 100 \mathrm{mg}\end{array}$ & $\begin{array}{l}\text { Naproxen } 2 \times 250 \mathrm{mg} \text {, } \\
\text { prednisone } 10 \mathrm{mg}(\text { reduced to } 7.5 \mathrm{mg} \S), \\
\text { methotrexate } 17.5 \mathrm{mg}\end{array}$ \\
\hline
\end{tabular}

DMARD $=$ Disease modifying antirheumatic drug

§Second course of treatment; ffirst course of treatment only. 

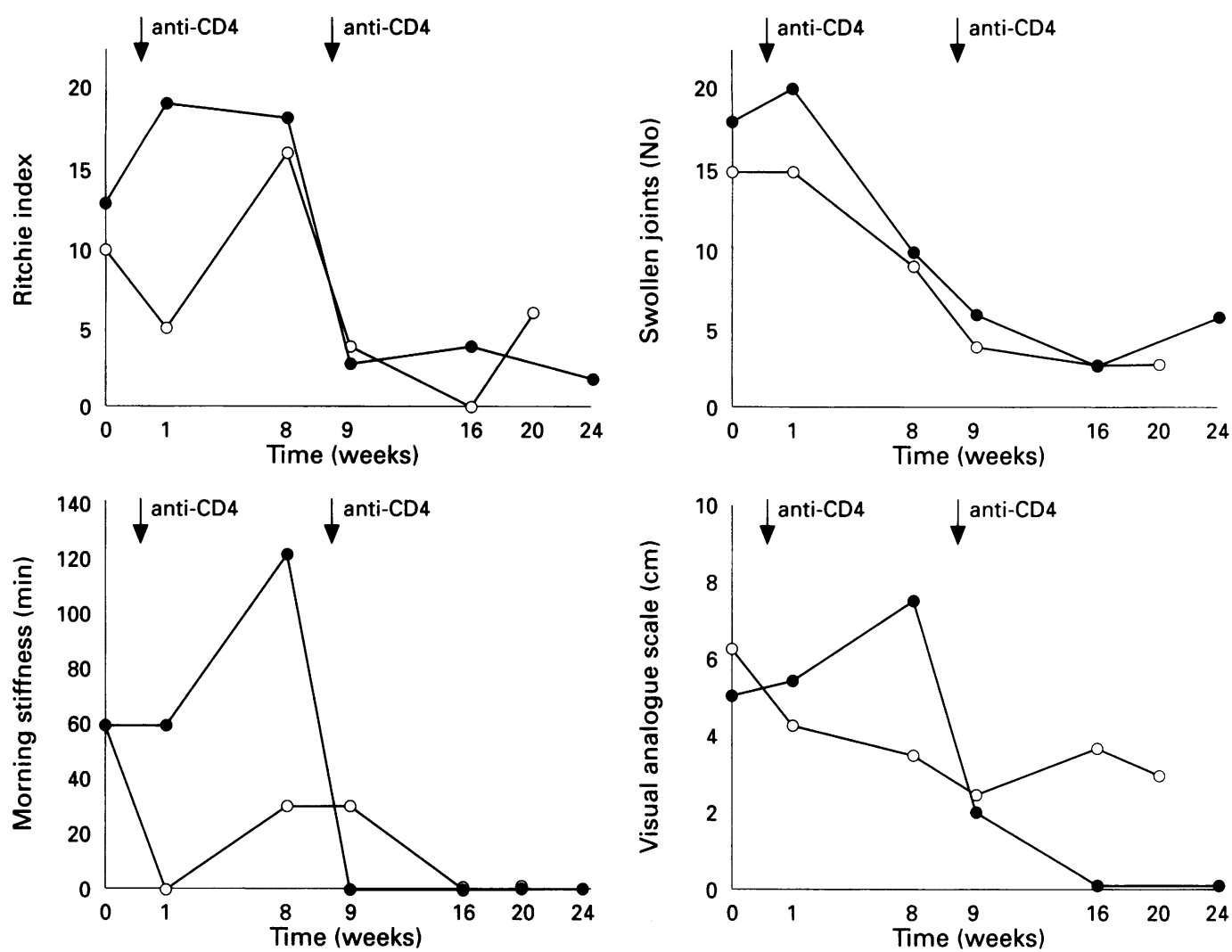

Changes in clinical parameters of disease activity in patient $1(0)$ and patient $2(\bullet)$, in response to treatment with CD4 antibodies, on seven study days during weeks 1 and 9 (arrows) after treatment. Patients were asked to mark a $10 \mathrm{~cm}$ visual analogue scale, between bad $(10 \mathrm{~cm})$ and good $(0 \mathrm{~cm})$ to indicate their assessment of their condition.

further infusions well. Human antimouse immunoglobulin activity could be detected in both patients after two treatment courses. There were no alterations in organ function, and no infections were observed either during treatment or during a six months follow up observation period.

\section{Discussion}

From our observations we conclude that treatment with CD4 antibodies is feasible in children with systemic onset JCA, with limited side effects. It led to a significant but transient reduction in $\mathrm{CD} 4$ cell count which lasted from a few days to some weeks but did return to normal values, even after a second course of treatment. There were immediate beneficial clinical effects of treatment in one patient, while in the other marked beneficial effects were achieved only by repeated treatment. These effects could not be attributed to longstanding treatment with immunosuppressants.

Both patients suffered from a highly active disease refractory to all conventional treatments previously applied. Disease activity required continuation of immunosuppression by cyclosporin or methotrexate. It is interesting to note that, even under these difficult conditions, the anti-CD4 treatment provided relief and clinical improvement by reduction in articular pain score, morning stiffness, and joint swelling for a limited period of time. In the first patient (the boy), fever disappeared even though the steroid dosage was reduced after anti-CD4 treatment. CRP levels were reduced in both patients, indicating a systemic anti-inflammatory effect. ${ }^{3}$ We studied a third child who had 'adult type' RA and whose data provided a 'disease control' case. This 12 year old girl (data not provided) with primarily seronegative polyarticular JCA, received a single course of anti-CD4 after chloroquine, gold, azathiprine, and methotrexate had failed. This resulted in a decrease in Ritchie index (from 75 to 44 ), morning stiffness (from 120 to 15 minutes), number of swollen joints (from 23 to 13), and a considerable shift of disease assessment $(7 \cdot 2$ to $3 \cdot 8)$, comparable to effects observed after anti-CD4 treatment in adult RA patients. CRP levels decreased from 173 to 86 $\mathrm{mg} / \mathrm{l}$ immediately after the treatment, but increased again four weeks later.

Although the small number of patients investigated does not allow definitive conclusions to be drawn from our study, observations suggest a transient clinical and serological response to the treatment. As our experience in adult RA patients was limited to a single repetition of the $\mathrm{CD} 4$ antibody treatment, both these child patients have since received another experimental treatment (cyclophosphamide pulse treatment).

It is important to note that in another study (presented to the ACR Meeting in 1994 by Bredfeld $e t a l$ ) using a different and humanised chimeric CD4 antibody in a placebo controlled trial in RA (not JCA) patients, the initial encouraging data could not be confirmed. Unfortunately, the initial anti-CD4 trials were performed with a panel of different CD4 antibodies and differing procedures and cannot easily be compared. However, none of these 
observations can be applied to JCA because systemic onset JCA, in particular, is a different disease, which shares only a few similarities with RA.

In common with our previous experiences with anti-CD4 treatment, only occasional and minor side effects were observed which probably resulted from short lived cytokine peaks. ${ }^{14}$ Both patients developed small, but detectable amounts of human antibodies to mouse immunoglobulin, and these might have caused urticaria in the first patient. It may be that antimouse immune responses will prevent long term use of the antibody. A multicentre study of RA patients taking methotrexate has reported that treatment with a chimerised CD4 antibody ${ }^{75}$ can lead to longlasting depletion of CD4 cells. Further, there are reports on long term depletion of CD4 cells with these antibodies in patients who did not receive additional cytostatic drugs. ${ }^{6}$ The reduction in CD4 counts produced by MAX.16H5 was only transient; the counts returned to normal values even after repeated treatment and under additional medication by immunosuppressive drugs.

These preliminary observations provide supportive evidence of positive effects of antiCD4 treatment in systemic JCA, but long term efficacy remains to be established.

The authors wish to thank Prof Dr Oppermann, Children's Hospital Cottbus, and Dr I Huppertz, Department of Paediatrics, University of Würzburg, for their interest in referring patients to our institution for this treatment.

Supported by the Bundesministerium für Forschung und Technologie (FKZ 01 ZU 8607/1).
1 Janossy G, Duke O, Poulter L W, Panayi G, Bofill M, Goldstein G. Rheumatoid arthritis: a disease of T-lymphocyte/macro

2 Herzog C H, Walker C H, Pichler W, et al. Monoclonal antiCD4 in arthritis. Lancet 1987; ii: 1461-2.

3 Horneff G, Burmester G R, Emmrich F, Kalden J R Treatment of rheumatoid arthritis with an anti-CD4 monoclonal antibody. Arthritis Rheum 1991; 34: 129-40.

4 Wendling D, Wijdenes J, Racadot E, Morel-Fourrier B Therapeutic use of monoclonal anti-CD4 antibody in rheumatoid arthritis. $\mathcal{F}$ Rheumatol 1991; 18: 325-7.

5 Reiter C, Kakavand B, Rieber E P, Schattenkirchner M Riethmüller $G$, Krüger $K$. Treatment of rheumatoid Riethmüller G, Krüger $K$. Treatment of rheumatoid
arthritis with monoclonal CD4 antibody M-T151. arthritis with monoclonal CD4

6 Van der Lubbe P, Reiter C, Reithmüller G, Sandwer M Breedveld F C. Treatment of rheumatoid arthritis (RA) with chimeric CD4 monoclonal antibody. Arthritis Rheum 1991; 34: S89.

7 Moreland L W, Bucy R P, Tilden A, et al. Use of a chimeric monoclonal anti-CD4 antibody in patients with refractory rheumatoid arthritis. Arthritis Rheum 1993; 36: 307-18.

8 Horneff G, Sack U, Kalden J R, Emmrich F, Burmester G R. Reduction of monocyte-macrophage activation markers upon anti-CD4 treatment. Clin Exp Immunol 1993; 91: 207-13.

9 Emmrich F. Empfehlungen für die Herstellung und Prüfung in vivo applizierbarer monoklonaler Antikörper. Dtsch in vivo applizierbarer monoklona
Med Wochenschr 1987; 112: 194-8.

10 Ritchie D M, Boyle J A, McInnes J M, et al. Clinical studies with an articular index for the assessment of joint tenderness in patients with rheumatoid arthritis. $Q \mathcal{F} M e d$ 1969; 147: 393-406

11 Burmester G R, Kalden J R, Peter H H, Schedel I, Beck P, Wittenborg A. Immunological and functiona characterization of peripheral blood and synovial fluid lymphocytes from patients with rheumatoid arthritis. Scand F Immunol 1978; 7: 405-17.

12 Horneff G, Winkler T, Emmrich F, Kalden J R, Burmester $G R$. Human anti-mouse antibody response induced by R. Human anti-mouse antibody response induced by anti-CD4 monoclonal antibody therapy in patients with 59: 89-103

13 Cassidy J T, Levinson J E, Bass J C, et al. A study of classification criteria for a diagnosis of juvenile rheumatoid arthritis. Arthritis Rheum 1986; 29: 274-81.

14 Horneff G, Krause A, Emmrich F, Kalden J R, Burmester G R. Elevated levels of circulating tumor necrosis factor$\alpha$, interferon- $\gamma$, and interleukin 2 in systemic reaction induced by anti-CD4 therapy in patients with rheumatoid arthritis. Cytokine 1991; 3: 266-7.

15 Moreland L W, Pratt P W, Bucy R P, Jackson B S, Feldman J Woopman W J. Treatment of refractory rheumatoid arthritis with chimeric anti-CD4 monoclonal antibody. Long-term followup of CD4+ T cell counts. Arthritis Rheum 1994; 37: 834-8. 